\title{
Medievalista
}

Online

28 | 2020

Número 28

monges e bispos medievais em uma disputa pelas emoções públicas

\section{A Santidade Enfurecida}

monges e bispos medievais em uma disputa pelas emoções públicas

The Infuriated Holiness: Medieval Monks and Bishops in a Struggle for Public

Emotions

\section{Leandro Duarte Rust}

\section{(2) OpenEdition}

\section{Journals}

\section{Edição electrónica}

URL: http://journals.openedition.org/medievalista/3333

DOI: 10.4000/medievalista.3333

ISSN: $1646-740 \mathrm{X}$

Editora

Instituto de Estudos Medievais - FCSH-UNL

\section{Edição impressa}

Paginação: 279-310

Refêrencia eletrónica

Leandro Duarte Rust, «A Santidade Enfurecida», Medievalista [Online], 28 | 2020, posto online no dia 01 julho 2020, consultado o 23 março 2021. URL: http://journals.openedition.org/medievalista/3333 ; DOI: https://doi.org/10.4000/medievalista.3333

Este documento foi criado de forma automática no dia 23 março 2021.

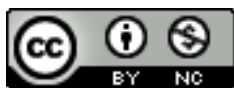

Mediavalista está licenciado com uma Licença Creative Commons - Atribuição-NãoComercial 4.0 Internacional. 
monges e bispos medievais em uma disputa pelas emoções públicas A Santidade Enfurecida monges e bispos medievais em uma disputa pelas emoções públicas The Infuriated Holiness: Medieval Monks and Bishops in a Struggle for Public Emotions

Leandro Duarte Rust

"Uma vez que os cristãos interiorizam a proibição
à ira e à vingança que lhes é imposta, desenvolve-
se neles um interesse apaixonado pela capacidade
de ira. Eles percebem que o enraivecer-se é um
privilégio ao qual eles renunciam em favor do
único ser que se pode enraivecer: Deus." (Peter Sloterdijk, 2010)

Um poder público dirige emoç̃oes. Ele as localiza, as transforma e direciona como ações coletivas. Entre as razões que levam uma pessoa ou um grupo a desempenhar o papel de autoridade está a eficiência em orquestrar os sentimentos, em dominar certos repertórios de comunicação dos afetos. Reger as maneiras de reconhecer e expressar as emoções afeta as tramas do poder, pois desloca o campo de oportunidades para legitimar a concentração de riqueza, coerção, prestígio. Esculpida pela lógica e pela razão instrumental, a geografia do público é constantemente talhada pela paixão e pela emoção mobilizadora. Seu traçado é obra conjunta desses dois artesãos: o logos e o pathos. Consequentemente, a emergência pública de uma força social é um processo heterogêneo, aberto a combinações inesperadas entre ideias e condutas, a sobreposições desconcertantes de propósitos e práticas que um observador externo (ou posterior) pode julgar incongruentes, disparatadas e até mesmo sem sentido algum.

o parágrafo anterior enuncia uma hipótese para um trabalho historiográfico. Trata-se de uma resposta provisória para a pergunta "historicamente, como ocorre a emergência ou a alternância de forças públicas?". Uma resposta de alcance restrito, ajustado a um objetivo preciso, comedido - se pode dizer. Seus limites têm a extensão do interesse pela dinâmica da mudança, a atenção às causas está além, noutro 
território. Aqui, nestas poucas páginas, busca-se compreender o como, não o porquê. Porém, ainda que circunscrita, essa hipótese articula um pressuposto de largo alcance, uma premissa que, graças a um rol crescente de estudos originais, tem se revelado a ideia guia para um admirável mundo novo de relações sociais: emoções são repertórios de organização do mundo. Um vigoroso debate tem sido travado em torno dessa ideia, sobre como decifrá-la. Atualmente, as perspectivas de maior repercussão sobre a literatura científica as definem como "algoritmos biológicos". A expressão é um indicador loquaz da distância percorrida pelo estudo das emoções. Quase não há espaço para tratá-las como reações de uma mecânica sensorial ou como efeitos da excitação que embriaga uma consciência. Cada vez mais longínquas das ideias de pulsões somáticas e de singularidades do eu interior, tais abordagens têm apresentado as emoções como condutas avaliativas, isto é, maneiras de encadear certos índices de convívio: elas prescrevem regras, perpetuam diferenças, ajustam finalidades, validam funcionalidades ${ }^{2}$. Entre os historiadores, esse deslocamento dos modos de interpretar parece ter alcançado visibilidade quando Barbara Rosenwein reformulou o conceito de "regimes emocionais"3. Como regime, os afetos compõem um sistema implícito através do qual as comunidades se realizam, estabelecendo o que é valioso e o que é prejudicial a seus integrantes. Como regime, portanto, emoções são performances políticas do cotidiano e concentram enorme potencial para repercutir sobre a constituição ou a desestruturação dos espaços de poder ${ }^{4}$. Entre os gatilhos que disparam essa potencialidade, estão as lutas pelo controle de postos e recursos institucionais.

Emoções instituem espaços políticos, enquanto a vida política temporaliza comunidades emocionais. Reencontramos o cerne da hipótese. Cabe agora testá-la, submetê-la ao crivo daquilo que os historiadores veem: as evidências. Embora faça as vezes de nome cabível a uma impressão diretamente criada pelo vivido, como uma marca deixada pelo peso dos traços característicos do real, uma "evidência" não é um fragmento desnudo das coisas e dos seres, mas uma artesania da percepção. Ou na elegante definição de François Hartog: a evidência não é a visão em si, mas o como se da visão; não é a imagem, mas a potência da imagem ${ }^{5}$. Antes de ser o sinal judicial da verdade - prova -, ela é uma ferramenta para fazer ver. Tal definição é o fio de Ariadne para a metodologia que resultou nas páginas a seguir, com as quais buscamos compreender uma história ambientada na península itálica, nas cercanias do ano 1000 . Época em que uma comunidade monástica protagonizou uma disputa política imprevisível, que a levou das raias da heresia às glórias do cardinalato; uma história de um julgamento divino, uma corte papal impiedosa, assassinatos noturnos, comoções populares e produção do direito.

Uma disputa pelas emoções públicas.

\section{Ardor}

Em pé, imóvel sob vestes sacerdotais, o monge mantinha o olhar vidrado sobre o caminho incandescente ${ }^{6}$. Segurando uma cruz com a imagem do Salvador, Pedro se deteve diante do calor inumano que imanava do chão. Horas antes, havia ali duas pilhas de lenha de grandes proporções: dez pés de comprimento, cinco pés de largura e quatro e meio de altura - segundo a medida da época. Com três metros de extensão, um e meio de espessura e um pouco menos de tamanho, os dois paredões de madeira haviam cumprido seu destino ao estalar como fogueiras de apetite aterrador. As chamas 
mastigaram vorazmente a lenha e cuspiram de volta uma larga trilha de carvão ardente. As brasas formavam uma camada tão espessa que os pés daquele que ali pisasse afundariam até os calcanhares ${ }^{7}$. E esse era o propósito. Para isso as fogueiras foram acesas sob o olhar estupefato de três mil pessoas naquela manhã de quarta-feira: criar o caminho flamejante que o monge deveria percorrer vagarosamente.

Pedro, então, tracejou o sinal da cruz contra fogo e brasa e, retorcendo as mãos ao redor do crucifixo, ergueu o joelho e embarcou na coluna de ar fervente. Com "a fisionomia de uma coragem inabalada", caminhou sobre as labaredas "com passos lentos e solenes". A cada instante, as chamas revoavam ao seu redor, "envolvendo-o por todas as direções", penetrando na camisa de linho, que estufava, percorrida por corredeiras de ar vulcânico. O calor soprava seus cabelos como um hálito infernal, agitando-os de uma parte a outra. Às suas costas, surgia uma trilha de pegadas enegrecidas, um rastro dos sulcos profundos criados a cada vez que os pés cavavam o chão de brilho avermelhado. 0 monge cumpriu toda a travessia. Ao final da marcha causticante, ele estava "miraculosamente ileso". Não apenas "seu corpo, todos os paramentos que portava pela virtude de Jesus Cristo" estavam intactos. As chamas o envolveram como se esquecidas da própria natureza, "sem deixar qualquer sinal de queimadura". 0 manípulo, a estola, as barras da batina: era inútil insistir, nada fora chamuscado. Nem mesmo os pelos dos pés, imersos no carvão ardente, haviam sido afetados, estavam intocados. Talhada no crucifixo, a presença de Deus privou o fogo do efeito natural: Sua bondade fez com que as "chamas o tivessem envolvido por todos os lados para manifestar a maravilhosa virtude do Salvador, não o poder da combustão". Pedro "não queimava porque sentia o ardor da fé católica. Certamente nosso Deus, que é um fogo devorador, era presente e contra a Sua vontade o fogo corpóreo não podia causar nenhum dano"'.

No dia 13 de fevereiro de 1068, Pedro, um monge florentino, teria se submetido a um ordálio do fogo. Sua vitória sobre essa dramática prova corporal se tornou a memória de uma proeza espiritual arrebatadora. O relato foi composto por outro religioso, Andrea'. Nascido por volta do ano mil, o autor é figura cercada por incertezas, mas o pouco que se sabe faz dele um personagem complexo. É tarefa penosa saber onde ele estava quando o caminho de brasas supostamente foi trilhado. Há indícios de que viajou para Milão anos antes; alguns registros o colocam de volta a Florença no início dos anos 1070. O paradeiro incerto entre 1067 e 1073 torna difícil considerá-lo uma testemunha ocular $^{10}$. Difícil, mas não impossível. Não se pode refutar que ele fosse um dos três mil rostos que presenciaram a proeza. Mas, a bem dizer, sabe-se que o relato foi redigido por volta de 1092, quase um quarto de século após o momento em que teria ocorrido. A narrativa pode ser um registro lavrado pelos olhos e, simultaneamente, urdido pela imaginação. E não é só a cronologia da versão que se revela escorregadia: a ortodoxia também.

Andrea havia tomado a estrada até Milão para se juntar aos seguidores de Arialdo, um diácono que liderava uma campanha de rejeição ao alto clero local. Há mais de dez anos ele surgira na terra milanesa. Primeiro, perambulara pelo interior rural, abordando quem passava pelas estradas para anunciar uma verdade terrível: ali, naquele canto do mundo, todas as almas estavam em perigo. Em pouco tempo, o diácono de feições tacanhas e voz trovejante ganhou o interior das muralhas e transformou ruas e praças em púlpito habitual. Em sermões frequentes, Arialdo denunciava o bispo e os clérigos, acusando-os de manter esposas e viver como magnatas mundanos. Violavam o celibato, 
rejeitavam a pobreza e se entregavam à caça, a jogatinas, bebedeiras, roupas ostensivas, ao luxo dos castelos. Em Milão, o clero evitava o reto caminho das virtudes, se afastava da luz espiritual, caía nas sombras da materialidade, negava Cristo - fulminava o diácono. Entre aqueles muros, as almas estavam mais próximas da perdição ${ }^{11}$. Os historiadores se referem a Arialdo como um reformador, mas o nome que se ouvia dos lábios de grande parte dos contemporâneos era outro: herege. O pregador de voz eletrizante e seus seguidores ganharam fama como adversários do poder episcopal, inimigos de uma instituição cristã e não só de "um" bispo. 0 antagonismo se difundiu rápido. Convocados por seu irmão milanês, numerosos bispos do norte itálico se reuniram em um sínodo que condenou o grupo e declarou que aquelas almas insolentes estavam marcadas com o ferrete da excomunhão ${ }^{12}$. Não foi o suficiente. As campanhas não cessaram. Na realidade, o antagonismo se intensificou e impulsionou uma guerra de propaganda, em que ambos os lados descreviam suas histórias por meio de episódios envolvendo visões, milagres e aparições para demonstrar a justiça de sua causa, legitimar suas decisões e edificar uma reputação gloriosa para suas condutas.

O relato sobre o ordálio do fogo é um desses episódios. Ele desponta como claro sinal de que Deus cerrava fileiras com o baixo clero citadino, com diáconos e monges como Pedro e Arialdo. Conquanto fosse abade do mosteiro de São Fedele de Strumi - posição que o eximia das obrigações e aflições do baixo clero -, Andrea narrou aquele episódio após ter escrito a Vida de São Arialdo. Aos seus olhos, o diácono condenado por heresia seguira o exemplo de Cristo, sacrificando-se pela fé e pela verdade. Seu alinhamento ideológico no conflito não poderia ser mais claro. Logo, o relato sobre o ordálio integra uma narrativa militante, engajada, elaborada para recrutar o real como instrumento de convencimento e de justificação. Ter sido ou não uma testemunha ocular não desfaz a condição de se tratar de uma recordação seletiva, interessada, elaborada para ajustar e corrigir acontecimentos - não meramente descrevê-los ${ }^{13}$. Mas e então? O que se pode demonstrar através de uma recordação como essa? Qual a sua relevância histórica? Aliás, ela é relevante? Sim. Ainda que o fato ali narrado seja uma fantasia, a invenção de algo que nunca ocorrera senão na imaginação de uma parcela dos florentinos, o sentido conferido a essa criação era real. A data, o cenário, a multidão e a proeza podem ser idealizações, qual elementos de um faz-de-conta tornado crível em função de privilégios, interesses e reputações implicados. No entanto, o sentido geral que lhe confere unidade e coerência é ocorrência história: a trama deslindada, o enredo que dispõe as peças do faz-de-conta numa ordem específica resulta de experiências que o narrador não controla, das quais não pode dispor livremente ${ }^{14}$. Ele não as controla porque não são fenômenos estritamente pessoais, e, sim, intersubjetivos, partilhados coletivamente - razão pela qual o relato podia ser reconhecido e considerado plausível por ouvintes e leitores que sequer sabiam da existência de Andrea. $O$ ordálio do fogo talvez nunca tenha ocorrido ${ }^{15}$, mas a maneira como ele é narrado tem um fundamento objetivo. O significado do relato é histórico. É preciso tentar decifrá-lo.

Um ponto de partida para a busca pode ser encontrado na caracterização da ação relatada. Voltemos à trama. Andrea foi incisivo ao identificar quem era o protagonista do ordálio. Não era o monge, mas Cristo. Pedro figura aí como um material humano através do qual a graça divina se desloca e desce dos céus para a terra, um condutor espiritual em sangue e pele. Ele não é o sujeito do relato, mas o instrumento animado que se coloca ao dispor do verdadeiro autor da cena, Deus. Por certo que o religioso é descrito como um portador de valores excepcionais. A narrativa o aclama: quando ele deu o primeiro passo fora da trilha incandescente, a multidão se lançou sobre ele 
extasiada; suas vestes foram agarradas por mãos ávidas, centenas de bocas beijaram-lhe os pés com fervor - detalhes fornecidos pela própria documentação. Todavia, o destinatário daqueles gestos de adoração não era o corpo mortal que acabara de resistir ao fogo: "todos exaltavam o Senhor com lágrimas de glória, convictos de que a palavra de Deus se manifestara" ${ }^{16}$. A ação narrada como um ordálio ultrapassa as fronteiras de um ato devocional - inspirado ou guiado por Deus. Sua figuração é de uma ação efetivamente divina, de um desdobramento da presença celeste. As vozes que rodopiavam o ar em júbilo eram dirigidas aos ouvidos a Deus (miserabilis ad Deum voces mittendo). $\mathrm{O}$ ardor que fez o fogo das lenhas esquecer a própria natureza imanava do Criador, era Sua vontade (Domini potentia) revelando-se ${ }^{17}$. A caracterização torna plausível uma dedução: o episódio se passa em meio a uma participação humana severamente restringida.

O relato está estruturado sobre essa premissa. $\mathrm{O}$ que quer que fosse indicado como motivo para a realização do ordálio não afetaria a caracterização do monge e dos florentinos como agentes que careciam de meios de ação. Não havia outra opção disponível a não ser reunir coragem sobre-humana e esperar por um milagre (miraculum): que Deus recompensasse um sacrifício pessoal suspendendo o funcionamento que Ele mesmo conferiu à natureza, impedindo que as brasas varassem um corpo puro, inocente. A crença ressignificava um dado histórico, redizendo com temas da fé inefável uma realidade demasiado concreta: o dramático caso de uma comunidade que enfrentava a escassez de oportunidades para agir, que estava, por alguma razão, encurralada pelas relações sociais ao seu redor. Impedida ou desacreditada em seu recurso a competências e a condutas humanas, só restava apelar ao ardor divino, essa "maravilhosa" "virtude do Salvador" (mirabilia, virtus Salvatoris). Essa noção de "maravilhoso" empregada pelo relato é um topos retórico: falar em algo que ocorre maravilhosamente (mirabiliter) é conferir autoridade ao visual, àquilo que se pode admirar com os olhos: se o ouvinte não foi testemunha ocular do narrado, cabe a ele acatar a autoridade da imagem apresentada sobre a lógica ${ }^{18}$. Na época em que o abade Andrea escrevia, o maravilhoso se impunha ao racional - como percebeu Jacques Le Goff ${ }^{19}$. No entanto, mencionar uma "maravilha" era também uma maneira de situar o limite da ação humana. 0 maravilhoso frequentemente surgia quando uma comunidade já não podia contar com outros grupos ou instituições.

$\mathrm{O}$ ardor divino era o contra-ataque da memória sobre a impotência para interferir no curso de certas relações sociais. No milagre das chamas, a revanche simbólica sobre a derrota em alguma disputa pelo poder. Que disputa?

\section{Frustração}

A comunidade monástica à qual foi atribuído o ordálio do fogo teria nascido de uma rixa deflagrada por volta de 1034. Naquele ano, a cizânia se alastrou pelo riquíssimo mosteiro florentino de São Miniato. Um monge se recusou a aceitar o abade eleito por seus irmãos. Ao que parece, o religioso, João Gualberto, havia amealhado liderança suficiente para se rebelar contra Umberto, o novo superior ${ }^{20}$. Como o desacato violava deveres monásticos, João buscou apoio externo, indo aconselhar-se com um eremita influente na região, certo Teuzo. $O$ conselheiro era um ancião experimentado naquele tipo de assunto, tendo vivido algo muito similar. Ele havia deixado seu mosteiro de origem após desentender-se com o abade. Desterrado, Teuzo adotou uma vida 
incomum: não deixou de ser monge, mas não se juntou a outra congregação, tampouco fundou uma casa religiosa. Na realidade, sequer fora longe. Instalou-se nas proximidades do mosteiro, levando uma vida duríssima. Suas frequentes autoflagelações eram comentadas entre a população local e logo renderam-lhe a reputação de homem santo e, com ela, generosas doações dos habitantes de Florença e dos príncipes itálicos. $\mathrm{O}$ eremita desertor era uma figura controversa, ambígua. $\mathrm{O}$ "ancião famosíssimo e de imensa reputação" (magnum et famosissimum senem) era venerado por imperadores - Conrado II e Henrique III estavam entre os peregrinos que buscavam seu conselho e cuja gratidão era demonstrada com valiosos regalia -, administrava a riqueza que a piedade popular sedimentava ao seu redor com uma cascata de oferendas, mas não estava sob a vigilância de um superior, de uma regra monástica e não observava o silêncio prescrito pela tradição. Para muitos contemporâneos, uma vida confusa, desajustada, um homem às vésperas da cegueira espiritual. Entre as lideranças cristãs, era censurado como o praticante de uma vida religiosa equivocada, "mais suscetível à voz da turba do que à da própria consciência" ${ }^{21}$.

$\mathrm{O}$ encontro com Teuzo deixou profundas marcas em João. Ao retornar, ele reuniu uma parcela dos irmãos de claustro e os dirigiu para o "foro público da cidade" (foro publico civitatis). Ladeado pelos companheiros, ele pregou em plena praça do mercado, bradando a remoção do abade e condenando o bispo local, responsável por aprovar aquela eleição que, João sentenciava, não passara de uma negociata vergonhosa da autoridade espiritual. Mas a medida da indignação escapou ao controle dos acusadores. Seguiu-se um tumulto. A denúncia acendeu o pavio do ódio popular, que explodiu na presença do jovem monge: "não queremos que seja removido, queremos que seja morto" 22 - teria gritado a multidão. Nem o abade, nem o bispo foram mortos. 0 desfecho daquela irrupção coletiva foi outro: João deixou o mosteiro de São Miniato. Tornou-se errante, instalando-se provisoriamente em uma comunidade religiosa, depois em outra, e em outra... Até alcançar Aquabella, a um dia de distância de Florença, onde ele estabeleceu um eremitério conhecido pelo nome de "Vallombrosa". A primeira menção documental ao novo estabelecimento é de 27 de janeiro de 1037. A fundação prosperou rapidamente. Promovido a prior, João Gualberto, recebeu das famílias locais a propriedade sobre outros mosteiros: São Pedro in Moscheto, São Paulo in Razzuolo, São Cassiano in Monte Scalari. Em algum momento entre 1040 e 1046, uma poderosa linhagem de condes, os Cadolingi, colocou a abadia de São Salvador di Settimo sob sua direção nominal. Em 1048, uma pequena igreja foi doada aos monges, que a consagraram a São Salvi: era o início do convento que levaria o nome daquele santo - e que será um palco crucial na história da comunidade. Em pouco mais de uma década, Vallombrosa saltou do patamar de edificação idealizada por um monge andarilho para o de uma congregação numerosa, socialmente enraizada, inserida nas redes da dominação aristocrática local. No mesmo ano, 1048, os monges adotaram a regra beneditina, marca espiritual de sua consolidação patrimonial ${ }^{23}$.

A expansão sobre a paisagem rural não desfez o fracasso inicial. Vallombrosa era obra de homens movidos por uma espiritualidade urbana. Teuzo e Gualberto eram filhos de um monasticismo singular, orientado para a mobilização popular e que zelava pela "voz da multidão" ao invés da solidão contemplativa do "deserto espiritual", o claustro. Como notou Kaspar Elm, a vida religiosa modelada por suas condutas implicava uma participação direta nas tensões sociais da cidade, onde acreditavam ser travada a luta contra os erros e os vícios, adversários mortais da Libertas Ecclesiae - a "Liberdade da Igreja" ${ }^{24}$. 0 espaço urbano florentino permanecia além de sua crescente influência. Não 
se pode esquecer que o apelo primordial ao fervor popular terminara desastrosamente: a tentativa de fazer a voz das ruas ecoar o clamor pela deposição do abade Umberto saíra de controle. $\mathrm{O}$ desfecho transformou João Gualberto na figura itinerante que fundou Vallombrosa, mas o manteve longe do "foro público", seu berço espiritual. Agora, como prior de uma congregação que amealhara imensa fortuna em terras, rendas e reputação espiritual, ele estava em condição de voltar à carga e reparar a frustração. Mas a conquista religiosa de Florença seria uma empresa dificílima. Um concorrente à altura havia surgido. A cidade tinha um novo bispo.

\section{Escândalo}

Os registros documentais sobre o prelado recém-chegado são minguados. Contudo, há o suficiente para considerar que Pedro Mezzabarba foi, quase imediatamente, a face de uma nova época para a autoridade episcopal. Os florentinos prestaram-lhe juramento logo após a eleição para o episcopado, em $1062^{25}$. Um dos primeiros gestos do novo pastor de almas foi doar, a título de livello, a igreja de São Procolo de Florença, juntamente com todas as suas possessões, ao abade de Santa Maria da Badia em troca de uma pensão anual de doze denários de prata. Comum entre o clero da época, esse tipo de acordo, o livello, permitia cumprir o papel de benfeitor de mosteiros, sendo uma das maneiras mais eficientes para apresentar-se como continuador das tradições locais, como o legítimo sucessor dos bispos falecidos à frente da igreja florentina. Além disso, a doação muito provavelmente levara seu nome até os salões da mais poderosa linhagem aristocrática de todo o norte itálico: os canossanos. A abadia em questão contara recentemente com generosos atos de proteção da marquesa de Canossa, Beatriz, que, por meio de sentença pública, havia assegurado a inviolabilidade de todos os bens supervisionados pelo abade em um raio de duas milhas daquela mesma igreja e do mosteiro no lugar chamado Mandria ${ }^{26}$. Entre 1062 e 1066, o novo bispo concluiu aquela que se tornaria sua principal realização: a reedificação da hospedaria (hospitio) do mosteiro da Badia. O próprio abade louvara o empenho do bispo, que assegurou a restituição de todo patrimônio já doado para a hospedaria ${ }^{27}$. Numa época que monumentalizava a ideia de Igreja, quando o acesso ao sagrado cristão era delimitado no espaço e contido com formas arquitetônicas, ${ }^{28}$ assegurar a integridade das possessões eclesiásticas era edificar a comunhão espiritual. Mezzabarba agia como bispo exemplar, que, por fortalecer a unidade florentina, a poupava do fracionamento e da dissidência, mantendo-a intacta e purificada. Progressivamente, ele cumpria os requisitos sociais que asseguraram a muitos outros dignitários da época uma reputação de "reformador".

Não aos olhos vallombrosanos. Os monges viam Mezzabarba como concorrente pelo foro público. Enquanto o bispo atuava como patrono eclesial, os religiosos percorriam as ruas acusando-o de ter recebido a autoridade pastoral em troca de dinheiro, muito dinheiro. As pregações parecem ter se iniciado no próprio ano da eleição, em 1062. Mas, pelo que se viu há pouco, as enérgicas investidas retóricas não surtiram o efeito desejado. Mezzabarba seguia desempenhando a função regularmente e seus atos eram acolhidos como legítimos por outras casas monásticas. Os seguidores de Gualberto, então, aguçaram o antagonismo. Em 1065, o denunciaram à Sé Apostólica. Os rumores de que o pai de Pedro havia obtido o episcopado para o filho pela polpuda soma de 3.000 libras embasaram uma carta que informava o Papa Alexandre II: a cabeça da igreja 
florentina estava publicamente tomada pela simonia ${ }^{29}$. Uma acusação difícil de ser confirmada.

Um dos maiores combatentes do tráfico material de bens clericais e dignidades espirituais (simonia) era o cardeal-bispo Pedro Damião. Suas campanhas incansáveis circulavam por muitas paisagens através de cartas pessoalmente ditadas. Duas de suas epístolas, de 1066, contêm os argumentos de um debate farpado com dois capelães itálicos sobre a natureza da simonia. Damião não faz qualquer alusão a irregularidades no episcopado de Florença: e não era do seu feitio ignorar um caso tão próximo e do conhecimento da Santa Sé $^{30}$. No ano seguinte, o próprio pontífice se correspondeu com o acusado. Já ciente da denúncia, Alexandre fez chegar às mãos de Mezzabarba o privilégio em que confirmava a proteção apostólica à sua recente fundação, o mosteiro de São Pedro Maior. Por linhas elogiosas, o papa tratava o homem incriminado pelos vallombrosanos por "caríssimo filho Pedro, o bispo de Florença" ${ }^{31}$. É pouco provável que esse fosse o tratamento reservado pelo papado para um simoníaco. Ao que tudo indica, Alexandre enxergava no destinatário a iluminada figura do dignitário local que fundara um mosteiro feminino, dotando-o sozinho de bens e rendas. Ele não era o único. $O$ ato de fundação atesta que o bispo agira respaldado pelo testemunho do marquês de Canossa em pessoa, Godofredo, além "de todos os clérigos e laicos de Florença" ${ }^{32}$. Há indícios suficientes para afirmar que Mezzabarba tenha sido um dos muitos casos identificados por Rudolf Schieffer de eclesiásticos acusados de simonia não porque a tivessem cometido, mas porque a denúncia era dotada de imenso potencial comunicativo e jurídico. Antes de ser a marca de uma "verdade", denunciar alguém como um "ladrão espiritual" era uma tática promissora para deslegitimá-lo e provocar sua ruína entre o clero ${ }^{33}$. Apresentada ao mundo como uma evidência, a tática foi um caminho sem volta.

A escalada de tensões foi aguda; a discórdia, irrefreável. Nos meses seguintes, os monges multiplicaram as pregações. Suas vozes pairavam sobre ruas e mercados. Respaldado por um histórico de cooperação cultivado com outros bispados, especialmente os de Volterra e Todi, ocupados por prelados imperiais, João Gualberto enviou um grupo de cônegos até a corte de Henrique IV, para que averiguassem o ingresso de Mezzabarba no episcopado. Enquanto isso, uma névoa de rumores sinistros se adensava ao redor do bispo. As notícias eram cada vez mais perturbadoras. Em Roma, o cardeal Damião relatava que chegara aos seus ouvidos que os vallombrosanos administravam o batismo em três pias sem aspergir o santo crisma porque o que estava disponível fora consagrado por Mezzabarba. Não só. Em razão do comportamento dos monges, quase mil pessoas se convenceram de que era melhor morrer sem os sacramentos do que recebê-los de mãos clericais ordenadas pelo bispo ${ }^{34}$. Que retaliava. Por ordem sua, em 1066, os cônegos foram privados do direito de administrar as próprias possessões. Pouco depois, uma notícia acirrou os ânimos.

Arialdo, o austero diácono milanês seguido pelos vallombrosanos, surgiu flutuando sobre um espelho d'água. As marcas de tortura naquele corpo inchado pelo frio lago Maggiore indicavam que o bispo retomava a ferro o controle sobre a igreja e a cidade vizinhas. A causa do baixo clero desmoronava. De Milão sopravam ventos favoráveis à retomada da hegemonia do poder episcopal ${ }^{35}$. Esse giro da roda da fortuna parece ter encorajado um grupo de cavaleiros, homens de Mezzabarba, a selar suas montarias sob o manto da noite e fazê-las deitar espuma sobre as rédeas. Eles desmontaram às portas do convento de São Salvi. Os monges foram surpreendidos em pleno altar. As orações foram interrompidas pelo tilintar das espadas, o conhecido anúncio de que as bainhas 
estavam soltas à cintura. A cena seguinte é aterrorizante. Um dos monges teve o crânio instantaneamente rachado. Outro foi golpeado na altura dos olhos tão impiedosamente que parte do nariz, do lábio superior e muitos dentes pendiam do rosto, presos à barba. Outro, com o ventre fendido, tentava reter as entranhas entre dedos sôfregos. Após o ataque, os cavaleiros saquearam o altar e atearam fogo, não sem antes arrancar as roupas dos religiosos, deixados nus e semimortos ${ }^{36}$.

Deste ponto em diante, Roma se envolveu diretamente. Pedro Damião chegara à cidade - não se sabe se antes ou depois do ataque a São Salvi, pois a cronologia não é precisa ${ }^{37}$. A bem dizer, o cardeal não havia sido enviado pelo papa: a força da amizade com cônegos motivara a viagem até Florença. Não obstante falasse apenas em nome de seus interesses pessoais, Damião exortou "o clero e o povo" a encaminharem o caso para julgamento em Roma, em um concílio da Santa Sé38. Assim foi feito. Na quaresma, os vallombrosanos compareceram a uma assembleia convocada por Alexandre. A decisão se revelaria fatal.

O pontífice não os via com bons olhos. Ele mesmo o dissera. Alguns anos antes, a abadia de Vallombrosa foi um dos destinatários da epístola em que o papa advertia sobre o dever elementar de todo religioso: separar-se do mundo. A Regra de São Bento e o Concílio da Calcedônia exigem que monges se mantenham dentro dos muros do mosteiro, proibidos de pregar nos campos, nas cidades e fortificações - repreendia o texto ${ }^{39}$. Outra carta, de datação incerta, mas que parece mencionar o que transcorria entre 1065 e 1066, gravou a indignação de Alexandre ao saber que cônegos florentinos buscaram a corte imperial para arbitrar a elevação do bispo ${ }^{40}$. 0 concílio não era um tribunal favorável à causa daqueles monges. Mas o que era desaprovação se metamorfoseou em hostilidade no momento que Pedro Damião tomou a palavra. Sua boca ressoava como a trombeta de um anjo vingador: "senhor Papa, eis os gafanhotos que destroem o verdor da Santa Igreja!" ${ }^{41}$. Esses monges se tornaram tão heréticos quanto a simonia que denunciam - disse o cardeal. Desprezaram a missa e rejeitaram os sacramentos ministrados por sacerdotes. Amaldiçoando bençãos e absolvições como atos meramente humanos, eles pisotearam as graças que o Altíssimo derrama sobre a humanidade - Damião era mordaz. Por sua causa, centenas deixaram este mundo sem receber o corpo e o sangue de Cristo $^{42}$. Os demais bispos logo fizeram eco ao alarme de escândalo, vociferando que os florentinos foram contaminados pela blasfêmia, vaidade e desobediência daqueles monges caídos em desgraça. O plenário encolerizado teria proclamado a condenação não fosse a interferência de um diácono romano chamado Hildebrando de Soana ${ }^{43}$.

Encerrou-se o concílio sem sentença; nenhuma decisão foi formalmente anunciada. Nada parecia ter mudado - exceto para os vallombrosanos. A assembleia pincelou cores ainda mais trágicas sobre sua comunidade. Quando deixaram Roma, estavam à beira da derrota. O efeito político foi o de um isolamento no interior da eclesiologia itálica. Já não podiam contar com os "reformadores" milaneses, em debandada desde o assassinato de Arialdo; o episcopado da região tomara o partido de Mezzabarba, que contava ainda com o suporte das grandes famílias senhoriais, entre elas os canossanos; a corte imperial não entraria em rota de colisão com Alexandre, com quem se reconciliara há pouco ${ }^{44}$; o pontífice e o clero romano estavam dispostos a entregá-los aos bispos como "ovelhas aos lobos" - segundo um cronista daquela época ${ }^{45}$. Os monges não dispunham da aliança com uma força social expressiva. Não havia um poder ou uma autoridade disposta a respaldar suas acusações. Ao menos não neste mundo. 


\section{Fúria}

Pedro, um monge vallombrosano, ocupa o centro da cena no ordálio do fogo, mas não era o personagem terreno mais importante naquela trama repleta de maravilhoso. Esse lugar de honra cabe ao "povo de Florença" (populi Florentini). Na narrativa de Andrea, o povo envia uma carta ao papa anunciando que a prova das chamas despiu a "lepra simoníaca" de Mezzabarba perante o juiz justo e supremo - Deus. Aqui, uma ressalva: "povo" não é um vocábulo classista. Ele não caracteriza uma classe ou nomeia a confluência de certos extratos sociais. Trata-se de um vocábulo político: "povo" é uma prosopopeia do espaço público, a cidade metaforizada como humanidade, dotada de voz, consciência e emoções. Tal função representacional é razão para o termo ser intercambiável com outro, a "plebe" (plebi Florentinae). Tais nomes emergem para tornar tangível um argumento decisivo: a cidade tomara o partido dos monges, cuja ação era inquestionavelmente pública ${ }^{46}$. Ênfase ampliada pela declaração de que a decisão de realizar o ordálio contara com o apoio da maior parte do clero secular, dos distintos integrantes do Capítulo da igreja de São João Batista - os cônegos - e dos padres das ordens menores ${ }^{47}$. Segundo o cronista, a decisão era apenas o mais recente desdobramento do clamor popular suscitado pela crueldade do bispo e seus homens. Eis a sequência de acontecimentos que se lê na carta.

No dia 9 de fevereiro, no sábado que precedia o início do jejum quaresmal, padres foram caçados à luz do dia pelo magistrado da cidade. A mando do bispo, ele os perseguiu até a igreja de São Pedro in Ciel d'Oro, invadiu o sacrossanto recinto e arrastou para fora os acusados de recusar obediência a Mezzabarba. Ao testemunhar tamanho "crime" (scelere concursus), quem estava presente foi arrebatado por uma comoção indizível. Os homens levaram as mãos à cabeça em gestos nervosos, como se arrancassem os próprios cabelos, no que foram seguidos pelas mulheres, que agitaram os véus e, desgrenhadas, começaram a bater duramente sobre o próprio tórax, gritando e suplicando a Deus com "triste lamento pela morte de seus homens e filhos". A grita rapidamente se voltou contra os clérigos que foram deixados na igreja. Em meio aos lamentos rasgados, "os homens e, especialmente, as mulheres católicas" (catholicorum virorum et maxime feminarum) os chamavam, aos berros, de asseclas de um criminoso espiritual. Os gritos de cúmplices foram rapidamente sucedidos pelo rugido de "heresia! heresia!". Amedrontados, os sacerdotes fecharam as portas do santuário e interromperam a missa. Essa dramática reação é a primeira descrição de um apelo popular à fúria celestial: a uma manifestação divina capaz de "defender a fé católica e, combatendo a heresia simoníaca, destruí-la" (catholicam fidem [...] defendere et symoniacam haeresim impugnando destruere). Um clamor pela aniquilação ${ }^{48}$.

No dia seguinte, ainda aturdidos pela comoção (acclamabamur), os clérigos recorrem aos monges, para que, juntos, encontrassem uma maneira de pôr um fim àquele conflito que se prolongava, sangrento e traumatizante: era preciso "dissipar toda dúvida e conhecer a verdade". Em poucas horas, o mensageiro enviado ao mosteiro de São Salvador retornou com a notícia de que os religiosos conheciam um procedimento que continha a "virtude do Salvador" (virtus Salvatoris) e que, como tal, era capaz de "eliminar toda a dúvida dos corações". Eles se propunham a realizá-lo em três dias. A revelação teria lugar na quarta-feira. $O$ clero aderiu unanimemente. A segunda e a terça seriam passadas em orações, nas quais todos implorariam a Deus para que a verdade, a 
única palavra que seria obedecida, fosse revelada, e que "seus efeitos recaíssem sobre o inimigo" (veritatis huius reseraret hostium) ${ }^{49}$. Aqui, façamos ponto. É preciso ser enfático. A história relembrada por Andrea não é apenas uma busca pela verdade. Mas, isto sim, uma busca pela verdade transmissora de uma emoção divina: a fúria justiceira. Sua narrativa rege o ritmo de uma revelação que eclodiria como a sentença desapiedada que desceria sobre um adversário há muito tempo impune. A face enfurecida de Deus seria a vara que conduziria a cidade de Florença para a unidade. Como o resultado esperado era a restauração da união citadina, o "povo" era o personagem imprescindível. Razão pela qual é ele quem inaugura e encerra os eventos do dia 13.

Na manhã de quarta-feira, três mil pessoas estavam diante do mosteiro escolhido pelos vallombrosanos. Um dos "servos de Deus", então, se dirige à multidão: "irmãos, porque vos reunis aqui?". Segundo Andrea, "todos os clérigos e laicos, de ambos os sexos e todas as idades" (omnibus clericis et laicis promiscui sexus et etatis) responderam em uníssono: "para que abandonemos o erro e sigamos a verdade". A voz inquisidora volta à carga: "e de que modo, assim ordenamos, desejam ser iluminados?". E, mais uma vez: "prove, com um fogo de grandes proporções, isto que sustentais sobre Pedro [Mezzabarba]". o povo não apenas proclama o ordálio como é descrito erguendo as pilhas de lenha que formariam a trilha de brasas. Uma vez preparado o madeiro seco, a liturgia foi celebrada. Mas o ato exclusivamente clerical não diminui a relevância atribuída à multidão. Andrea afirma que todos cantavam com máxima devoção, "não só o coro dos monges e o clero, mas também os laicos, que choravam copiosamente" (chorus monachorum et clericorum necnon et laicorum ex corde lacrimatur). Enquanto o Agnus Dei era entoado, quatro monges foram até as pilhas de lenha: o primeiro, portando a imagem do Cristo crucificado; o segundo, água benta; o terceiro, doze velas abençoadas acesas; o quarto, o turíbulo fumegante. Eles acenderam as chamas e então "o clamor geral se elevou aos céus" (His igitur visis clamor omnium in celum attollitur) ${ }^{50}$. Muitos homens, e um número ainda maior de mulheres, se voltavam para Maria, suplicando sua intervenção. Em mil direções ressoava o nome do apóstolo Pedro assegura o cronista.

Viris plurimumque a feminis: "pelos homens e ainda mais pelas mulheres" ${ }^{51}$. A ênfase na presença de mulheres é recorrente no relato. Talvez seja mais preciso afirmar que um uso estratégico da alusão às mulheres é recorrente. Nesse ponto, Andrea faz das palavras um contrapeso a uma das maiores vantagens reputadas ao bispo. Mezzabarba era o fundador de um mosteiro feminino consagrado a São Pedro Maior e que contava com a proteção pontifícia. Ao enfatizar a participação feminina na prova dirigida pelos monges, o relato qualifica os vallombrosanos como uma instância capaz de suprir uma demanda religiosa que vinha sendo publicamente absorvida pelo prelado. A narrativa maravilhosa surte um efeito jurídico ao apresentar a congregação como instituição capaz de prover às mulheres, publicamente, espaço para participar diretamente na comunicação com o sagrado. Afinal, o clamor que subia aos céus e roçava os ouvidos de Pedro e Maria era dos homens tanto quanto delas. Noutras palavras, as vozes femininas da narrativa não são necessariamente indícios de uma igualdade espiritual entre os gêneros, mas uma evidência da necessidade da abadia de Vallombrosa de se apresentar como um concorrente legítimo dos privilégios institucionais assegurados pelo papado ao bispo. A narrativa de Andrea foi composta para seduzir o olhar e convencê-lo de que as vozes das esposas e filhas florentinas eram mais numerosas e sonoras sob a direção monástica. Mas, essa potência visual não era um dado ou algum depoimento. Era uma 
técnica forjada para criar um efeito: tornar presente uma autoridade que João Gualberto e seus seguidores não possuíam ${ }^{52}$.

Mal havia saído do caminho ardente e o monge Pedro girou sobre os calcanhares, pronto a retornar às labaredas, mas foi "contido pelo povo" (capitur a populo). Os lábios que não buscavam tocar-lhe os pés cantavam aos céus, exaltando o Senhor por revelar a verdade. É relevante notar como a carta nomeia a natureza divina: "nosso Deus é fogo devorador" contra o qual o "fogo corpóreo" nada pode. Deus noster ignis consumens est ("nosso Deus é um fogo devorador") não é uma frase cunhada pela epístola. Essa a solicitou a um livro bíblico, tal como transcrito na Vulgata ${ }^{53}$. E a frase não parece ter sido a única referência buscada naquelas páginas. Muitos elementos da cena do ordálio ressurgem de uma leitura da Epístola aos Hebreus: o jugo imposto pelos pecadores, a resiliência para suportar repreensões, a devassidão profana que surge da venda de um direito sagrado. Mas chama especial atenção a fórmula de santidade aí mencionada: "fazei veredas direitas para os vossos pés, para que o que manqueja não se desvie inteiramente, antes seja sarado. Segui a paz com todos, e a santificação, sem a qual ninguém verá o Senhor" (12: 13-14, 29). É o arquétipo do ordálio vallombrosano. Narrando aquela fria manhã de fevereiro, a epístola redizia a Sagrada Escritura. É impossível saber onde termina a autoridade bíblica e onde começa a realidade florentina. Mas isto é certo: os monges de João Gualberto trouxeram de volta à vida uma emoção que, segundo a Epístola aos Hebreus, um dia açoitara a mente de Moisés. 0 sentimento terrível, assombroso, de estar na presença de Deus, juiz de todos, que prometera: “ainda uma vez comoverei, não só a terra, senão também o céu” (12:26). Os vallombrosanos tornaram-se instrumentos da vontade inefável, do fogo que consome, destrói e aniquila no céu e na terra. Os derrotados canalizaram a fúria da santidade.

As Sagradas Escrituras não teriam sido as únicas páginas a ganhar vida naquele dia. 0 que quer que tenha ocorrido em 13 de fevereiro de 1068 foi uma performance jurídica de alto rendimento. Ao tornar os florentinos partícipes da santa fúria, os monges cumpriam à risca uma exigência do Digesto. Essa seção da obra monumental compilada por ordem do imperador Justiniano no longínquo ano de 533 carregava a autoridade para determinar o que era público. A definição, curta e certeira: "direito público é aquilo que compete ao estado das coisas romanas" ${ }^{54}$. Como notou Maria Filomena Coelho, nessa formulação, a palavra "estado" não era uma referência a um aparato governamental ou a algum conjunto de instituições centralizadas. Status significa aí "uma condição das coisas romanas" ${ }^{55}$. O termo se refere ao que pertence ao populus, ao que caracteriza particularidades do "povo". Esse é precisamente um dos sentidos maiores da narrativa de Andrea. O ordálio é a forma visível de algo que dizia respeito singularmente ao "povo da cidade de Florença" (populus Florentinae civitatis). Redizendo a Vulgata e o Digesto, o relato sobre a prova do fogo é a narrativa de uma experiência controlada de manipulação da produção do direito e, como tal de localização da conduta pública. Expressadas como crença maravilhosa, as emoções ocupavam posição central na capacidade de construir a cooperação, expressar a agressão, intermediar a derrota e, finalmente, apresentar-se como um legítimo detentor da faculdade de julgar. Apelar à santificação pela fúria divina modificou o campo de ação disponível aos vallombrosanos ou, no mínimo, legitimou a ação do que quer que, naquela manhã de fevereiro, tenha ocorrido, deslocando tal campo. Modificação coroada com a deposição de Mezzabarba naquele mesmo ano e com a elevação do monge Pedro - posteriormente conhecido como "Pedro Igneo" - a cardeal da Sé Romana. Com o "indubitável prestígio adquirido por Pedro Igneo graças à prova do fogo" ${ }^{56}$, instituições eclesiásticas citadinas 
estavam finalmente abertas à influência dos monges de Vallombrosa, que contavam agora com duas novas frentes para reaver seu berço espiritual, o "foro público": o bispado e o cardinalato.

No século XI, um poder público dirige emoções.

\section{BIBLIOGRAFIA}

Fontes impressas

ALEXANDRE II - Epistolas. PL 146: 1330.

ANDREA DE STRUMI - Vita Sancti Arialdi. MGH 30/2.

ANDREA DE STRUMI - Vita Sancti Johanni Gvalberti. MGH SS 30/2.

ANDREA DE STRUMI - Vita. AASS Iul.

ARNULFO - Gesta archiepiscoporum Mediolanensium. MGH SS 8.

ATO DE PISTOIA - Vita Altera. AASS Iul. 3.

ATO DE PISTOIA - Vita Sancti Iohannis Gvalberti. PL 146.

BERNOLDO DE COSTANÇA - De solution iuramentorum. MGH Ldl 2.

BONIZO DE SUTRI - Liber Ad Amicum. MGH Ldl 1.

CONRADO II - Diplomae. MGH DD K II.

corpus iuris civilis. Vol.2. Codex Justinianus. Berlim: Weidmannos, 1906.

D’ACUNTO, Nicolangelo; SARACENO, Lorenzo (Org.) - Opere di Pier Damiani: Lettere (41-67). Roma: Città Nuova, 2002.

DESIDERIO DE MONTE CASSINO - Dialogi de Miraculis sancti Benedicti. MGH SS 30/2.

GAROFALO, Salvatore (Ed.) - Biblia sacra Vulgatae editionis Sixti V Pont. Max. iussu recognita et Clementis VIII auctoritate edita. Editio emendatissima apparatu critico instructa, cura et studio Monachorum Abbatiae Pontificiae Sancti Hieronymi in Urbe Ordinis Sancti Benedicti. Turim: Marietti, 1965.

LANDOLFO - Historia Mediolanensis. MGH 8: 76-96.

MOSIICI, Luciana (Ed.) - Le carte del monastero di San Miniato al Monte (secoli IX-XII). Florença: Olschki, 1990.

PIATOLLI, Renato (Ed.) - Le Carte della canonica della cattedrale di Firenze. Florença: Istituto storico italiano per il Medio Evo, 1938.

PEDRO DAMIÃO - Epistolas. MGH Briefe 2.

SCHIAPARELLI, Luigi (Ed.) - Le Carte del monastero di. S. Maria di Firenze (Badia). Vol.1. Roma: Ermanno Loescher, 1913.

SIGEBERTO DE GEMBLOUX - Chronica. MGH SS 6: 363. 
UGHELLI - Italia Sacra, 3.

vita Sancti Iohannis Gvalberti Anonyma. MGH SS 30/2: 1106.

Estudos

ADOLPHS, Ralph; ANDLER, Daniel - "Investigating Emotions as Functional States Distinct from Feelings". Emotion Review 10/3 (2018), pp. 191-201.

ANGELINI, Roberto - La "Vita Sancti Iohannis Gualberti" di Andrea da Genova. Florença: Sismel/Ed. Del Galuzzo, 2011.

ANGELINI, Roberto - "Iniuriam pertulit: dell'offesa ricevuta dal beato padre Giovanni Gualberto, fondatore di Vallombrosa, durante il soggiorno a Camaldoli: testimonianze, reticenze e trasformazioni nella tradizione agiografica". in SALVESTRINI, Francesco (Ed.) - Monaci e pellegrini nell'Europa medievale: viaggi, sperimentazioni, conflitti e forme di mediazione. Florença: Ed. Polistampa, 2014, pp. 157-168.

APECITI, Ennio - “Andrea di Strumi, beato (sec. XI)”. Dizionario dela Chiesa Ambrosiana. Vol.1. Milão: NED, 1987, pp. 145-146.

BACK, Dominik; DAYAN, Peter - "Algorithms for survival: a comparative perspective on emotions”. Nature Reviews/Neuroscience 18 (2017), pp. 311-319.

BOESCH GAJANO, Sofia - “Storia e tradizioni vallombrosane”. Bullettino dell'Istituto Storico Italiano per il Medio Evo 76 (1964), pp. 99-125.

BOUCHERON, Patrick - "Palimpsestes ambroisienes: la commune, la liberte et le saint patron (Milan, XIe-XVe siècle)”. in CHASTANG, Pierre (Dir.) - Le Passé à l'Épreuve du Présent: appropriations et usages du passé du Moyen Âge à la Renaissance. Paris: PUPS, 2008, pp. 15-37.

BOVO, Claudia Regina - Em busca da Renovatio cristã: simonia e institucionalidade eremítica na correspondência de Pedro Damiano (1041-1072). Campinas, São Paulo: Unicamp, 2012. Tese de Doutorado.

CASTANHO, Gabriel - “A construção de uma comunidade sensível: corpo, afeto e emoção nos escritos de Guigo I (Grande Cartuxa, 1109-1136)”. Pasado Abierto 9 (2019), pp. 34-59.

COELHO, Maria Filomena - "Um universo plural: política e poderes públicos na Idade Média (séc. XII-XIII)". in TORRES FAUAZ, Armando (Ed.) - La Edad Media en perspectiva latinoamericana. Heredia: Ed. de la Universidad Nacional de Costa Rica, 2018, pp. 145-146.

COLLINGWOOD, Robin George - A Ideia de História. Lisboa: Ed. Presença, 2001.

D' ACUNTO, Nicolangelo - “Lotte religiose a Firenze nel secolo XI: aspetti della rivolta contro il vescovo Pietro Mezzabarba”. Aevum 66/2 (1993), pp. 279-312.

D’ ACUNTO, Nicolangelo - “Pietro Igneo”. in Dizionario Biografico degli Italiani, vol. 83 (2015) [Consultado a 13 novembro 2019]. Disponível em http://www.treccani.it/enciclopedia/pietroigneo_(Dizionario-Biografico).

DAMERON, George - "The cult of St Minias and the struggle for power in the diocese of Florence, 1011-1018”. Journal of Medieval History 13/2 (1987), pp. 125-141.

DAMERON, George - Episcopal Power and Florentine Society (1000-1320). Cambridge: Harvard University Press, 1991.

DASTON, Lorraine; PARK, Katharine - Le Meraviglie del Mondo. Mostri, prodigi e fatti strani dal Medioevo all'Illuminismo. Roma: Carocci, 2000. 
DE CERTEAU, Michel - História e psicanálise: entre ciência e ficção. Belo Horizonte: Autêntica, 2001.

DI FEBO, Martina - Mirabilia e Merveille: le trasformazioni del meraviglioso nei secoli XII-XV. Macerata: Edizioni Università di Macerata, 2015.

ELM, Kaspar - "La Congregazione di Vallombrosa nello Sviluppo della vita religiosa altomedievale". in COMPAGNONI, Giordano Monzio (Org.) - I Vallombrosani nella società italiana dei secoli XI e XII. Vallombrosa: Ed. Vallombrosa, 1995, pp. 13-34.

EWALD, Paul - “Die Papstbriefe der Britischen Sammlung”. Neues Archiv der Gesellschaft für ältere deutsche Geschichtskunde 5 (1880), pp. 274-414.

GINZBURG, Carlo - "Controlando a evidência: o juiz e o historiador”. in NOVAIS, Fernando; SILVA, Rogério (Org.) - Nova História em Perspectiva. São Paulo: Cosa \& Naify, 2011, pp. 341-358.

GOLINELLI, Paolo - "I Vallombrosani e I movimenti patarinici". in COMPAGNONI, Giordano Monzio (Org.) - I Vallombrosani nella società italiana dei secoli XI e XII. Vallombrosa: Ed. Vallombrosa, 1995, pp. 35-56.

GOLINELLI, Paolo - La Pataria: lotte religiose e social nella Milano dell'XI secolo. Milão: Europía-Jaca Book, 1984.

HARARI, Yuval Noah - Homo Deus: Uma breve história do amanhã. São Paulo: Companhia das Letras, 2016.

HARTOG, François - Memória de Ulisses: narrativas sobre a fronteira na Grécia Antiga. Belo Horizonte: Editora da UFMG, 2004.

HARTOG, François - Evidência da História: o que os historiadores veem. Belo Horizonte: Autêntica, 2017.

HOWE, John McDonald - Before the Gregorian Reform: the Latin Church at the turn of the first millenium. Ithaca: Cornell University Press, 2016.

IOGNA-PRAT, Dominique - La Maison Dieu: une histoire monumentale de l'Église au Moyen Âge. Paris: Seuil, 2006.

JESTICE, Phyllis G. - Wayward monks and the religious revolution of the eleventh century. Leiden: Brill, 1997.

KARANT-NUNN, Susan C. - The Reformation of Feeling: Shaping the Religious Emotions in Early Modern Germany. New York: Oxford University Press, 2010.

LE GOFF, Jacques - O Maravilhoso e o Quotidiano no Ocidente Medieval. Lisboa: Edições 70, 1990.

LEYSER, Henrietta - Hermits and the New Monasticism: A Study of Religious Communities in Western Europe 1000-1150. Nova York: Macmillan Publishers Limited, 1984.

LUCCHESI, Giovanni - "Per una Vita di San Pier Damiani. Componenti cronologiche e topografiche”. in San Pier Damiano. Nel IX centenario della morte (1072-1972). Vol.1. Cesena: Centro studi e ricerche sulla antica provincia ecclesiastica ravennate, 1972, pp. 13-179.

MEADE, Denis - "'From Turmoil to Solidarity: The Emergence of the Vallumbrosan Monastic Congregation". The American Benedictine Review 19 (1968), pp. 323-357.

MICCOLI, Giovanni - Pietro Igneo: studi sull'età gregoriana. Roma: Istituto Storico Italiano per il Medio Evo, 1962.

MICCOLI, Giovanni - Chiesa Gregoriana: ricerche sulla Riforma del secolo XI. Roma: Herder, 1999. 
MILO, Yuram - Tuscany and the Dynamics of Church Reform in the Eleventh Century. Stanford, CA: Stanford University, 1979. Ph.D. Thesis.

MOORE, Robert Ian - "Family, Community, and Cult on the Eve of the Gregorian Reform". Transactions of the Royal Historical Society 5 (1980), pp. 49-69.

NAGY, Piroska - "Collective Emotions, History Writing and Change: The Case of the Pataria (Milan, Eleventh Century)". Emotions: History, Culture, Society 2/1 (2018), pp. 132-152.

ROMERO, Mariza - “Entrevista: François Hartog”. Revista Brasileira de História 35/70 (2015), pp. 281-291.

RONZANI, Mauro - "Pietro Mezzabarba e I suoi confratelli". in BALOSSINO, Simones; GARBARINO, Gian Battista (Org.) - Organizzatione ecclesiastica nel tempo di San Guido: istituzioni e territorio nel secolo XI. Acqui Terme: Impressioni Grafiche, 2007, pp. 139-186.

ROSENWEIN, Barbara H. - Emotional Communities in the Early Middle Ages. Ithaca: Cornell University Press, 2006.

ROSENWEIN, Barbara H. - "Problems and Methods in the History of Emotions". Passions in Context: International Journal for the History and Theory of Emotions [em linha] 1 (2010). [Consultado a 6 julho 2019]. Disponível em: http://www.passionsincontext.de.

ROSENWEIN, Barbara H. - “Worrying about Emotions in History”. American Historical Review 107 (2010), pp. 821-845.

RUST, Leandro Duarte - “A autoridade, o desejo e a alquimia da política: linguagem e poder na constituição do papado medieval (1060-1120)". Varia Historia [em linha] 27/45 (2011), pp. 161-187 [Consultado a 6 julho 2019]. Disponível em https://doi.org/10.1590/S0104-87752011000100008].

RUST, Leandro Duarte - Bispos Guerreiros: violência e fé antes das cruzadas. Petrópolis: Vozes, 2018.

SALA, Torello (Ed.) - Dizionario Storico Biografico di scrittori, letterati ed artisti dell'ordine di Vallombrosa. Vol.1. Firenze: Iacobus Faber, 1929.

SCHIEFFER, Rudolf - "Spirituales Latrones. Zu den Hintergrunden der Simonieprozesse in Deutschland zwischen 1069 und 1077”. Historisches Jahrbuch 92 (1972), pp. 19-60.

SLOTERDIJK, Peter - Ira e Tempo: ensaio político-psicológico. Belo Horizonte: Estação Liberdade, 2010.

SOMERS, Margaret - "The Narrative Constitution of Identity: a relationship and network approach". Theory and Society 23/5 (1994), pp. 605-660.

SPINELLI, Giovanni; ROSSI, Giustino (Org.) - Alle Origini di Vallombrosa: Giovanni Gualberto nella societá dell'IX secolo. Milão: Europía-Jaca Book, 1984.

UTZ, Richard - Medievalism: A Manifesto. Kalamazoo: ARC Humanities Press, 2017.

VOLLRATH, Hannah - "L'accusa di simonia tra le fazioni contrapposte nella lotta per le investitura". in VIOLANTE, Cinzio; FRIED, Johannes (Ed.) - Il Secolo XI: una svolta? Bolonha: Il Mulino, 1993, pp. 131-156.

ZHUANG, Jyun-Rong; GUAN, Ya-Jing; NAGAYOSHI, HAYATO; YUGE, LOUIS; LEE, Hee-Hyol, TANAKA, Eiichiro. "Two-Dimensional Emotion Evaluation with Multiple Physiological Signals". Advances in Affective and Pleasurable Design. AHFE (2018); vol 774, 2019, pp. 158-168. 


\section{NOTAS}

1. ADOLPHS, Ralph; ANDLER, Daniel - "Investigating Emotions as Functional States Distinct from Feelings”. Emotion Review 10/3 (2018), pp. 191-201; BACK, Dominik; DAYAN, Peter - “Algorithms for survival: a comparative perspective on emotions". Nature Reviews/Neuroscience 18 (2017), pp. 311-319; ZHUANG, Jyun-Rong; GUAN, Ya-Jing; NAGAYOSHI, Hayato; YUGE, Louis; LEE, Hee-Hyol; TANAKA, Eiichiro - "Two-Dimensional Emotion Evaluation with Multiple Physiological Signals". in Advances in Affective and Pleasurable Design. Proceedings of the AHFE 2018 International Conference on Affective and Pleasurable Design, July 21-25, 2018, Loews Sapphire Falls Resort at Universal Studios, Orlando, Florida, USA. Ed. Shuichi Fukuda. S.l.: Springler, 2019, pp. 158-168. Ver ainda: HARARI, Yuval Noah - Homo Deus: Uma breve história do amanhã. São Paulo: Companhia das Letras, 2016, pp. 90-157.

2. Para um panorama da trajetória da "História das Emoções", ver: CASTANHO, Gabriel - "A construção de uma comunidade sensível: corpo, afeto e emoção nos escritos de Guigo I (Grande Cartuxa, 1109-1136)". Pasado Abierto 9 (2019), pp. 34-59.

3. Ver: ROSENWEIN, Barbara H. - "Worrying about Emotions in History". American Historical Review 107 (2002), pp. 821-845; ROSENWEIN, Barbara H. - Emotional Communities in the Early Middle Ages. Ithaca: Cornell University Press, 2006; ROSENWEIN, Barbara H. - "Problems and Methods in the History of Emotions". Passions in Context: International Journal for the History and Theory of Emotions [em linha] 1 (2010) [Consultado a 6 julho 2019]. Disponível em http:// www.passionsincontext.de.

4. KARANT-NUNN, Susan C. - The Reformation of Feeling: Shaping the Religious Emotions in Early Modern Germany. New York: Oxford University Press, 2010.

5. HARTOG, François - Evidência da História: o que os historiadores veem. Belo Horizonte: Autêntica, 2017, pp. 11-16, 203-204. Ver ainda: ROMERO, Mariza - "Entrevista: François Hartog". Revista Brasileira de História 35/70 (2015), pp. 281-291.

6. Um esclarecimento. Como o leitor poderá notar desde aqui, faço um uso explícito de recursos estilísticos na composição do enredo histórico, especificamente da dramatização. Uma expressão como "olhar vidrado" é de minha lavra e não será encontrada na documentação. Mas não faço tal uso de maneira inadvertida ou descuidada - na realidade, sequer espontânea. Trata-se de um procedimento metodológico controlado e planejado. Sua aplicação foi integralmente regida por três critérios: 1) a seletividade da análise histórica deve ser evidenciada como procedimento narrativo, ao invés de ocultada sob o frágil verniz de um pretenso mimetismo documental (portanto, recorro à dramatização para marcar minha ênfase em certas informações documentais); 2) tornar o elemento ficcional tangível é exigência para delimitar sua operacionalidade, ao invés de, quixotescamente, travar a batalha para negar sua presença performática na escrita acadêmica da história (neste caso, evidenciando-o na narrativa, busco vinculá-lo a uma categoria, a seletividade da leitura das fontes, mais do que a outras, como a construção de relações causais. Portanto, o leitor atento perceberá que trechos como esse ocupam um papel tão somente preliminar na maneira como apresento relações de causalidade entre os fenômenos históricos); 3) o recurso ficcional deve ser plausível à luz das informações documentais (logo, a dramatização obedece aos limites de um campo de possibilidades que não crio ou escolho arbitrariamente, já que demarcado a partir dos documentos). $\mathrm{O}$ esclarecimento é necessário em face da perpectiva corrente que apresenta tal procedimento como mero "recurso literário", expressão que, por seu turno, costuma implicar o juízo de tratar o estilo como uma forma sem conteúdo científico ou função analítica, uma "impureza" no rigor do conhecimento histórico. Em face dessa leitura, é preciso recordar lições aprendidas há quase um século: "nenhum historiador, nem mesmo o pior de todos, se limita a copiar suas fontes. Mesmo que não acrescente nada de seu [...] é ele que é responsável pelo que se passa”, como dizia R. G. Collingwood. Ou, nos termos mais diretos de Michel de Certeau, isso implica reconhecer que: "o aparato científico possui igualmente aspectos de ficção no trabalho do 
historiador" - a configuração narrativa é condição da escrita acadêmica da história. Faço uso de um recurso estilístico para evidenciar minha perspectiva, denunciar minha presença no texto e, assim, tornar mais transparente o direcionamento imposto a certo exercício de crítica e análise documental. É uma tentativa de evidenciar ainda mais minha práxis, ao invés de refugiar-me na pretensão erudita de que a historiografia meramente rediz um real original. Logo, é um modo de reconhecer que "a linguagem do historiador tem papel cognitivo e não meramente retórico", como lembrou Carlo Ginzburg. Modo arriscado, controverso - sem dúvida! Afinal, como advertiu Richard Utz, evidenciar a personalização da exposição científica cria o risco de fragmentar a história como disciplina, além de elevar o grau de instabilidade dos modelos interpretativos. Mas sigo o autor igualmente noutra constatação: tal prática é o passo adiante mais decisivo para a cientificidade das humanidades - e dos estudos medievais - atualmente. Ver: UTZ, Richard Medievalism: A Manifesto. Kalamazoo: ARC Humanities Press, 2017, especialmente pp. 1-16. Quanto às demais citações e sobre a própria argumentação presente nesta nota, ver: COLLINGWOOD, Robin George - A Ideia de História. Lisboa: Ed. Presença, 2001, pp. 244-259, especificamente p. 248; DE CERTEAU, Michel - História e psicanálise: entre ciência e ficção. Belo Horizonte: Autêntica, 2001, pp. 45-70, em especial p. 48; GINZBURG, Carlo - "Controlando a evidência: o juiz e o historiador". in NOVAIS, Fernando; SILVA, Rogério (Org.) - Nova História em Perspectiva. São Paulo: Cosa \& Naify, 2011, pp. 342-358, especificamente p. 358.

7. A descrição, incluindo as medidas das pilhas de madeira, consta em: ANDREA DE STRUMI - Vita Sancti Johanni Gvalberti. MGH SS 30/2: 1098-1099; ANDREA DE STRUMI - Vita. AASS Iul. 3: 359-361.

8. Todas as citações apresentadas nesse parágrafo e demarcadas entre aspas são retiradas do trecho a seguir: ANDREA DE STRUMI - Vita Sancti Johanni Gvalberti. MGH SS 30/2: 1098-1099; ANDREA DE STRUMI - Vita. AASS Iul. 3: 358-361. Sobre os detalhes da narrativa, ver também: MICCOLI, Giovanni - Pietro Igneo: studi sull'età gregoriana. Roma: Istituto Storico Italiano per il Medio Evo, 1962, pp. 150-154; SPINELLI, Giovanni; ROSSI, Giustino (Org.) - Alle Origini di Vallombrosa: Giovanni Gualberto nella societá dell'IX secolo. Milão: Europía-Jaca Book, 1984, pp. 108-114.

9. Tal autoria está cercada de controvérsias. O autor aqui selecionado como ancoragem documental é Andrea, abade de Strumi, cujo relato consiste na transcrição de uma carta enviada pelo clero e povo de Florença ao papa Alexandre II: tal epístola é a memória originária do relato, versão fundadora. Mas a correspondência de Alexandre não conta com um registro oficial; estruturado, organizado e preservado por uma chancelaria. Lidamos, portanto, com um universo documental repleto de incertezas: disperso, fragmentado, lacunar e, consequentemente, povoado por dúvidas e contestações. Diante desse cenário, parece-me consistente que a transcrição da epístola por Andrea seja tomada como parte do processo de construção histórica da autoria - e da autoridade - da mesma. A narrativa contida na missiva ganhou relevo histórico em razão de escolhas de Andrea. Ainda que não a tenha criado ex nihilo, Andrea foi o responsável por estabelecer essa versão, por perpetuar especificamente esse registro, como narrativa primordial do episódio, algo comprovado por sua incidência em versões posteriores, como a de Ato de Pistoia, composta posteriormente, no século XII. Para o conceito de "narrativa primordial" - modelo sociológico adotado para a configuração de autoria -, ver: SOMERS, Margaret - "The Narrative Constitution of Identity: a relationship and network approach". Theory and Society 23/5 (1994), pp. 605-660; especialmente 605-629. Além disso, já se aventou que o relato de Ato deveria ser considerado a versão mais adequada para se conhecer o ordálio, por ser uma versão mais detalhada e, supostamente, "mais completa". Quanto a isso, basta recordar que a versão de Ato é posterior e é, reconhecidamente, "um refazer do testemunho strumense, reelaborado [por Ato] de forma atenuada e acrecentado de detalhes específicos", conforme lembra ANGELINI, Roberto La "Vita Sancti Iohannis Gualberti" di Andrea da Genova. Florença: Sismel/Ed. Del Galuzzo, 2011, p. xxxii. 
10. Os indícios e registros aqui indiretamente mencionados constam em: SALA, Torello (Ed.) Dizionario Storico Biografico di scrittori, letterati ed artisti dell'ordine di Vallombrosa. Vol. 1. Firenze: Iacobus Faber, 1929, pp. 250-251; BOESCH GAJANO, Sofia - "Storia e tradizioni vallombrosane". Bullettino dell'Istituto Storico Italiano per il Medio Evo 76 (1964), pp. 99-125; ANGELINI, Roberto "Iniuriam pertulit: dell'offesa ricevuta dal beato padre Giovanni Gualberto, fondatore di Vallombrosa, durante il soggiorno a Camaldoli: testimonianze, reticenze e trasformazioni nella tradizione agiografica". in SALVESTRINI, Francesco (Ed.) - Monaci e pellegrini nell'Europa medievale: viaggi, sperimentazioni, conflitti e forme di mediazione. Florença: Ed. Polistampa, 2014, pp. 157-168.

11. Os registros documentais sobre a biografia e as pregações de Arialdo: ANDREA DE STRUMI Vita Sancti Arialdi. MGH 30/2: 1051-1070; LANDOLFO - Historia Mediolanensis. MGH 8: 76-96; ARNULFO - Gesta archiepiscoporum Mediolanensium. MGH SS 8: 18-25; BONIZO DE SUTRI - Liber Ad Amicum. MGH Ldl 1: 591-592. Ver ainda: MICCOLI, Giovanni - Chiesa Gregoriana: ricerche sulla Riforma del secolo XI. Roma: Herder, 1999, pp. 130-159; GOLINELLI, Paolo - La Pataria: lotte religiose e social nella Milano dell'XI secolo. Milão: Europía-Jaca Book, 1984, pp. 13-19; NAGY, Piroska "Collective Emotions, History Writing and Change: The Case of the Pataria (Milan, Eleventh Century)". Emotions: History, Culture, Society 2/1 (2018), pp. 132-152.

12. ARNULFO - Gesta archiepiscoporum Mediolanensium. MGH SS 8: 20; ANDREA DE STRUMI - Vita Sancti Arialdi. MGH 30/2: 1054-1056.

13. BOESCH GAJANO, Sofia - "Storia e tradizioni vallombrosane" ..., pp. 99-125; APECITI, Ennio "Andrea di Strumi, beato (sec. XI)". Dizionario dela Chiesa Ambrosiana. Vol. 1. Milão: NED, 1987, pp. 145-146; BOUCHERON, Patrick - "Palimpsestes ambroisienes: la commune, la liberte et le saint patron (Milan, XIe-XVe siècle)". in CHASTANG, Pierre (Dir.) - Le Passé à l'Épreuve du Présent: appropriations et usages du passé du Moyen Âge à la Renaissance. Paris: PUPS, 2008, pp. 15-37.

14. A argumentação adota o modelo heurístico para um exame narrativo proposto em: HARTOG, François - Memória de Ulisses: narrativas sobre a fronteira na Grécia Antiga. Belo Horizonte: EdUFMG, 2004.

15. Sobre os historiadores e o problema do realismo do ordálio: D' ACUNTO, Nicolangelo - "Pietro Igneo". in Dizionario Biografico degli Italiani, vol. 83 (2015) [Consultado a 13 novembro 2019]. Disponível em http://www.treccani.it/enciclopedia/pietro-igneo_(Dizionario-Biografico).

16. ANDREA DE STRUMI - Vita Sancti Johanni Gvalberti. MGH SS 30/2: 1099; ANDREA DE STRUMI Vita. AASS Iul. 3: 360 .

17. ANDREA DE STRUMI - Vita Sancti Johanni Gvalberti. MGH SS 30/2: 1098; ANDREA DE STRUMI Vita. AASS Iul. 3: 359.

18. Os termos miraculum, miracula e mirabiliter são reincidentes, surgindo em várias passagens documentais além do próprio enredo do ordálio. Ver: ANDREA DE STRUMI - Vita Sancti Johanni Gvalberti. MGH SS 30/2: 1083, 1089, 1098-1099; ANDREA DE STRUMI - Vita. AASS Iul. 3: 350-351, 356-361; ATO DE PISTOIA - Vita Altera. AASS Iul. 3: 370-382. Os termos miraculum e mirabiliter estão igualmente presentes na Vida de São Arialdo composta pelo abade strumense: ANDREA DE STRUMI - Vita Sancti Arialdi. MGH 30/2: 1058, 1070-1071, 1075.

19. LE GOFF, Jacques - O Maravilhoso e o Quotidiano no Ocidente Medieval. Lisboa: Edições 70, 1990. Ver igualmente: DASTON, Lorraine; PARK, Katharine - Le Meraviglie del Mondo. Mostri, prodigi e fatti strani dal Medioevo all'Illuminismo. Roma: Carocci, 2000; DI FEBO, Martina - Mirabilia e Merveille: le trasformazioni del meraviglioso nei secoli XII-XV. Macerata: Edizioni Università di Macerata, 2015.

20. Consagrada pelo bispo Hildebrando (1008-1025) em 1018, a abadia de São Miniato era uma das principais instituições de Florença. Bastião dos favores imperiais, a abadia resultava dos planos episcopais para expansão do controle sobre a região. Ver: MOSIICI, Luciana (Ed.) - Le carte del monastero di San Miniato al Monte (secoli IX-XII). Florença: Olschki, 1990, pp. 124-128; DAMERON, George - "The cult of St Minias and the struggle for power in the diocese of Florence, 1011-1018". Journal of Medieval History 13/2 (1987), pp. 125-141; MOORE, Robert Ian - "Family, Community, and 
Cult on the Eve of the Gregorian Reform". Transactions of the Royal Historical Society 5 (1980), pp. 49-69.

21. Sobre a reputação de santidade de Teuzo: ANDREA DE STRUMI - Vita Sancti Johanni Gvalberti. MGH SS 30/2: 1081; ANDREA DE STRUMI - Vita. AASS Iul. 3: 345-349; ATO DE PISTOIA - Vita Altera. AASS Iul. 3: 367-370. Quanto à influência junto à corte imperial, ver: CONRADO II - Diploma 273. MGH DD K II: 378; Vita S. Iohannis Gvalberti Anonyma. MGH SS 30/2: 1106. Sobre a reprovação por parte de seguimentos eclesiásticos da época, ver: PEDRO DAMIÃO - Epístolas 44 e 45 . MGH Briefe 2: 13, 34-39; D' ACUNTO, Nicolangelo; SARACENO, Lorenzo (Org.) - Opere di Pier Damiani: Lettere (41-67). Roma: Città Nuova, 2002, pp. 56-59, 84-91. Ver ainda: JESTICE, Phyllis G. - Wayward monks and the religious revolution of the eleventh century. Leiden: Brill, 1997, pp. 218-228.

22. ANDREA DE STRUMI - Vita Sancti Johanni Gvalberti. MGH SS 30/2: 1082. Ver ainda: ATO DE PISTOIA - Vita Sancti Iohannis Gvalberti. PL 146: 674-675; ATO DE PISTOIA - Vita Altera. AASS Iul. 3: 367.

23. SPINELLI, Giovanni; ROSSI, Giustino (Org.) - Alle Origini di Vallombrosa: Giovanni Gualberto nella societá dell'IX secolo ..., p. 30; MEADE, Denis - "From Turmoil to Solidarity: The Emergence of the Vallumbrosan Monastic Congregation". The American Benedictine Review 19 (1968), pp. 323-357, especificamente pp. 329-330; JESTICE, Phyllis G. - Wayward monks ... pp. 228-229; MILO, Yuram Tuscany and the Dynamics of Church Reform in the Eleventh Century. Stanford, CA: Stanford University, 1979. Ph.D. Thesis. pp. 172-176; DAMERON, George - Episcopal Power and Florentine Society (1000-1320). Cambridge: Harvard University Press, 1991, pp. 42-44.

24. ELM, Kaspar - "La Congregazione di Vallombrosa nello Sviluppo della vita religiosa altomedievale". in COMPAGNONI, Giordano Monzio (Org.) - I Vallombrosani nella società italiana dei secoli XI e XII. Vallombrosa: Ed. Vallombrosa, 1995, pp. 13-34. Para um panorama sobre o "novo monasticismo" que se difundiu pela Europa a partir do ano mil: LEYSER, Henrietta - Hermits and the New Monasticism: A Study of Religious Communities in Western Europe 1000-1150. Nova York: Macmillan Publishers Limited, 1984.

25. BERNOLDO DE COSTANÇA - De solution iuramentorum. MGH Ldl 2: 149. Ver ainda: RUST, Leandro Duarte - "A autoridade, o desejo e a alquimia da política: linguagem e poder na constituição do papado medieval (1060-1120)". Varia Historia [em linha] 27/45 (2011), pp. 161-187 [Consultado a 6 julho 2019]. Disponível em https://doi.org/10.1590/S0104-87752011000100008.

26. SCHIAPARELLI, Luigi (Ed.) - Le Carte del monastero di. S. Maria di Firenze (Badia). Vol.1. Roma: Ermanno Loescher, 1913, pp. 150-152, 146-148.

27. SCHIAPARELLI, Luigi (Ed.) - Le Carte del monastero..., pp. 158-165. Ver ainda: D' ACUNTO, Nicolangelo - "Lotte religiose a Firenze nel secolo XI: aspetti della rivolta contro il vescovo Pietro Mezzabarba". Aevum 66/2 (1993), pp. 279-312, especificamente p. 289.

28. IOGNA-PRAT, Dominique - La Maison Dieu: une histoire monumentale de l'Église au Moyen Âge. Paris: Seuil, 2006, pp. 331-360; HOWE, John McDonald - Before the Gregorian Reform: the Latin Church at the turn of the first millenium. Ithaca: Cornell University Press, 2016, pp. 86-112.

29. O advérbio "publicamente" - aqui considerado um indicador de se tratar de uma disputa eminentemente citadina pelo poder - se repete significativamente na documentação analisada, ver: ANDREA DE STRUMI - Vita Sancti Johannis Gvalberti. MGH SS 30/2: 1094; ANDREA DE STRUMI Vita. AASS Iul. 3: 357, 360-361.; Vita S. Iohannis Gvalberti Anonyma. MGH SS 30/2: 1106. Versão acatada por: DESIDERIO DE MONTE CASSINO - Dialogi de Miraculis Sancti Benedicti. MGH SS 30/2: 1146.

30. PEDRO DAMIÃO - Epístolas 140 e 141. MGH Briefe 3: 478-502; BOVO, Claudia Regina - Em busca da Renovatio cristã: simonia e institucionalidade eremítica na correspondência de Pedro Damiano (1041-1072). Campinas, São Paulo: Unicamp, 2012. Tese de Doutorado; D’ ACUNTO, Nicolangelo “Lotte religiose a Firenze nel secolo XI [...]” ..., pp. 294-295. 
31. ALEXANDRE II - Epístola a Pedro de Florença. PL 146: 1330.

32. UGHELLI - Italia Sacra 3: 75-76. Ver ainda: D' ACUNTO, Nicolangelo - "Lotte religiose a Firenze nel secolo XI [...]" ..., pp. 292-293.

33. SCHIEFFER, Rudolf - "Spirituales Latrones. $\mathrm{Zu}$ den Hintergrunden der Simonieprozesse in Deutschland zwischen 1069 und 1077". Historisches Jahrbuch 92 (1972), pp. 19-60. Sobre a retórica da simonia como estratégia jurídica: ver também: VOLLRATH, Hannah - "L'accusa di simonia tra le fazioni contrapposte nella lotta per le investitura". in VIOLANTE, Cinzio; FRIED, Johannes (Ed.) - Il Secolo XI: una svolta? Bolonha: Il Mulino, 1993, pp. 131-156; RONZANI, Mauro - "Pietro Mezzabarba e I suoi confratelli". in BALOSSINO, Simones; GARBARINO, Gian Battista (Org.) Organizzatione ecclesiastica nel tempo di San Guido: istituzioni e territorio nel secolo XI. Acqui Terme: Impressioni Grafiche, 2007, pp. 139-186, mais especificamente pp. 144-145.

34. PEDRO DAMIÃO - Epístola 146. MGH Briefe 3: 535-539; ANDREA DE STRUMI - Vita Sancti Johannis Gvalberti. MGH SS 30/2: 1094-1095, 1100; ANDREA DE STRUMI - Vita. AASS Iul. 3: 356-357. SIGEBERTO DE GEMBLOUX - Chronica. MGH SS 6: 363.

35. UGHELLI - Italia Sacra 3: 53-62; PIATOLLI, Renato (Ed.) - Le Carte della canonica della cattedrale di Firenze. Florença: Istituto Storico Italiano per il Medio Evo, 1938, pp. 114-116, 167. GOLINELLI, Paolo - "I Vallombrosani e I movimenti patarinici". in COMPAGNONI, Giordano Monzio (Org.) - I Vallombrosani nella società italiana dei secoli XI e XII. Vallombrosa: Ed. Vallombrosa, 1995, pp. 35-56, especificamente pp. 44-45.

36. A descrição da invasão ao mosteiro, incluindo a caracterização de ferimentos, golpes desferidos e cenário, encontram-se em: ANDREA DE STRUMI - Vita Sancti Johannis Gvalberti. MGH SS 30/2: 1094-1095; ANDREA DE STRUMI - Vita. AASS Iul. 3: 357; ATO DE PISTOIA - Vita Sancti Iohannis Gvalberti. PL 146: 691-693.

37. LUCCHESI, Giovanni - "Per una Vita di San Pier Damiani. Componenti cronologiche e topografiche". in San Pier Damiano. Nel IX centenario della morte (1072-1972). Vol. 1. Cesena: Centro studi e ricerche sulla antica provincia ecclesiastica ravennate, 1972, pp. 13-179, especificamente p. 59.

38. PEDRO DAMIÃO - Epístola 146. MGH Briefe 3: 531-542.

39. ALEXANDRE II - Epístola ao Clero e Povo Florentino. PL 146: 1406; EWALD, Paul - "Die Papstbriefe der Britischen Sammlung". Neues Archiv der Gesellschaft für ältere deutsche Geschichtskunde, vol. 5 (1880), pp. 274-414, especificamente p. 333.

40. EWALD, Paul - "Die Papstbriefe der Britischen Sammlung" ..., p. 340.

41. Vita S. Iohannis Gvalberti Anonyma. MGH SS 30/2: 1107.

42. PEDRO DAMIÃO - Epístola 146. MGH Briefe 3: 531-542.

43. Vita S. Iohannis Gvalberti Anonyma. MGH SS 30/2: 1107.

44. Para o conflito envolvendo Alexandre e a Corte: RUST, Leandro Duarte - Bispos Guerreiros: violência e fé antes das cruzadas. Petrópolis: Vozes, 2018.

45. LANDOLFO - Historia Mediolanensis. MGH 8: 77, 80-81. Ver: ARNULFO - Gesta archiepiscoporum Mediolanensium. MGH SS 8: 19; ANDREA DE STRUMI - Vita Sancti Arialdi. MGH 30/2: 1054.

46. Para as referências sobre populus e plebi: ANDREA DE STRUMI - Vita Sancti Johannis Gvalberti. MGH SS 30/2: 1096; ANDREA DE STRUMI - Vita. AASS Iul. 3: 358. O mesmo sentido povoa a redação da Vida de São Arialdo: ANDREA DE STRUMI - Vita Sancti Arialdi. MGH 30/2: 1053, 1058, 1064, 1066, $1069,1070$.

47. ANDREA DE STRUMI - Vita Sancti Johannis Gvalberti. MGH SS 30/2: 1096-1098; ANDREA DE STRUMI - Vita. AASS Iul. 3: 358-360.

48. Para todas as citações deste parágrafo: ANDREA DE STRUMI - Vita Sancti Johannis Gvalberti. MGH SS 30/2: 1097; ANDREA DE STRUMI - Vita. AASS Iul. 3: 359. O trecho que descreve a reação do "povo" - "arrancassem os próprios cabelos [...] agitaram os véus e, desgrenhadas, começaram a bater duramente sobre o próprio tórax, gritando e suplicando à Deus com "triste lamento pela morte de seus homens e filhos" - é quase uma tradução da seguinte passagem: “[...] velamina 
capitum a proicientium et passis ab crinibus flebiliter incedentium, pectora pugnis miserabiles ad Deum voces mittendo dure tundentium et super virorum ac filiorum mortem triste lamentantium".

49. ANDREA DE STRUMI - Vita Sancti Johannis Gvalberti. MGH SS 30/2: 1097; ANDREA DE STRUMI Vita. AASS Iul. 3: 359.

50. Para todas as citações deste parágrafo: ANDREA DE STRUMI - Vita Sancti Johannis Gvalberti. MGH SS 30/2: 1097-1098; ANDREA DE STRUMI - Vita. AASS Iul. 3: 359-360.

51. Ênfase que repercute também no clamor pela intervenção espiríto, afinal o ordálio era realizado em nome do Apóstolo Pedro e da Virgem Maria: ANDREA DE STRUMI - Vita Sancti Johannis Gvalberti. MGH SS 30/2: 1097-1098; ANDREA DE STRUMI - Vita. AASS Iul. 3: 359-360.

52. Ver: HARTOG, François - Evidência da História ..., pp. 253-264.

53. Versão utilizada para consulta: GAROFALO, Salvatore (Ed.) - Biblia sacra Vulgatae editionis Sixti V Pont. Max. iussu recognita et Clementis VIII auctoritate edita. Turim: Marietti, 1965.

54. Digesto 1.1,2. Ver: Corpus iuris civilis. Vol.2. Codex Justinianus. Berlim: Weidmannos, 1906.

55. COELHO, Maria Filomena - "Um universo plural: política e poderes públicos na Idade Média (séc. XII XIII)”. in TORRES FAUAZ, Armando (ed.) - La Edad Media en perspectiva latinoamericana. Heredia: Ed. de la Universidad Nacional de Costa Rica, 2018, pp. 145-146.

56. D’ ACUNTO, Nicolangelo - "Pietro Igneo" ...; ver também: MICCOLI, Giovanni - Pietro Igneo ..., pp. 150-154.

\section{RESUMOS}

A Europa do século XI foi marcada por conflitos eclesiásticos. Embora as tensões entre laicos e clérigos atraiam, há mais de um século, a maior parcela da atenção dos historiadores especialmente as chamadas lutas entre o sacerdócio e o império -, as disputas travadas entre segmentos da própria Igreja se multiplicaram e intensificaram, logrando grande repercussão documental. Entre os casos mais frequentes da escalada de embates na "Era da Reforma Gregoriana", estavam os confrontos entre monges e bispos, cuja eclosão repercutia em numerosas direções: sobre a dominação aristocrática, as cadeias de controle patrimonial, os fundamentos da eclesiologia, as mobilizações urbanas, os consensos jurídicos. As páginas a seguir consistem em um estudo sobre um caso assim: por volta de 1034, uma desavença opôs a alta cúpula do bispado florentino a uma parcela do monacato local preenchendo décadas com relatos de milagres aterradores, clamores populares, desafios abertos ao papado e disputas sangrentas pela autoridade jurídica. A análise histórica desse conflito articula crônicas, cartulários, epistolários e diplomática, orientada pela hipótese de que o campo de atuação dos agentes teria sido afetado por um fator singular: o desvelamento de certas emoções deslocava a geografia das prerrogativas públicas.

In the 11th century, Europe was marked by ecclesiastical conflicts. Although tensions between lay and clergy attracted, for more than a century, the largest share of the historians' attention especially the so-called struggles between the priesthood and the empire -, the struggles between segments of the Church itself multiplied and intensified, achieving great documentary repercussion. Among the most frequent cases of disputes during the "Gregorian Reformation Era" were clashes between monks and bishops, whose outbreak had repercussions in numerous 
directions: on aristocratic domination, patrimonial control networks, foundations of ecclesiology, urban mobilizations, legal consensus. The following pages consist of a study of such a case: around 1034 a quarrel opposed the high echelon of the Florentine bishopric to a portion of local monasticism filling in decades with reports of terrifying miracles, popular clamours, open challenges to the papacy and bloody disputes by legal authority. The historical analysis of this conflict articulates chronicles, cartulars, epistolary and diplomatic, guided by the hypothesis that the field of action of agents would have been affected by a singular factor: the unveiling of certain emotions shifted the geography of public prerogatives.

\section{ÍNDICE}

Keywords: Political History, Emotions, 11th century

Palavras-chave: História Política, Emoções, Século XI

\section{AUTOR}

\section{LEANDRO DUARTE RUST}

Departamento de História, Universidade de Brasília 70910-900 Brasília, Brasil.

leandro.rust@unb.br. https://orcid.org/0000-0002-7410-1635 